\title{
Analisis Kesalahan Imla' Mahasiswa Program Studi Pendidikan Bahasa Arab IAIN Salatiga
}

\author{
Roviin, Muh. Hafidz \\ Fakultas Tarbiyah Dan Ilmu Keguruan IAIN Salatiga \\ roviinrovi@gmail.com,muhafidz0108@gmail.com
}

\begin{abstract}
Received:
24-05-2020

Revised:

16-06-2020

Accepted:

30-06-2020
\end{abstract}

Article History:

\section{Keywords:}

Error analysis, Arabic language,

Imla'

\begin{abstract}
:
Imla' is one of the elements of Arabic language with a quite complex in writing, this problem is also faced by students of the Arabic Language Study Program at the State Islamic Institute of Salatiga. In this research, Imla's errors were collected through a written test. The analysis steps are carried out in three steps, first; collecting language errors data, second; identifying and classiffing language errors, third; explaining language errors and the correct language standards. Based on the analysis, the results are; 1). The error in writing letters that are similar in a word, 2). Lack of writing hama washal on words that should begin with hamza, 3). The error in writing al syamsiya on words that should not be written with al syamsiya, 4). The error in writing ta' marbutha, 5). The error in writing the mark of hamza in words beginning with the mark of ham za qatha', 6). The error in writing hamza in the middle of a word, 7). The error or lack of alif tafriq, 8). The error in writing alif layyina in the middle of a word, 9). The error in writing ta 'marbutha on certain words that should be written with ta' maftuha.
\end{abstract}

\section{Pendahuluan}

Kemampuan menulis dalam bahasa Arab membutuhkan penguasaan imla' dengan baik. Imla' merupakan salah satu cabang dari rumpun keilmuan bahasa Arab. Menurut Al Ghulayaini bahwa ilmu bahasa Arab terdiri dari beberapa rumpun antara lain sharf, i'rab, rasm, ma'ani, bayan, badi', arudh, qawafi, syi'r, insya', khitabah, tarikh adab dan matan lughah. ${ }^{1}$ Jadi menurut Al Ghulayini bahwa rumpun ilmu bahasa Arab terdiri dari tiga belas macam ilmu. Al Ghulayini tidak secara tegas menyebut imla' sebagai cabang ilmu, tetapi beliau menyebut dengan istilah rasm yang substansinya juga sama dengan imla' atau keterampilan menulis.

\footnotetext{
${ }^{1}$ Mustafa Al-Ghalayini, Jamial-Durus Al-Arabiyah (Darul Fikir, 2009).
} 
Menulis merupakan kemampuan menggunakan pola-pola bahasa secara tertulis. Keterampilan menulis juga dapat diartikan sebagai kemampuan mendiskripsikan atau mengungkapkan isi pikiran, mulai dari aspek yang sederhana sampai pada aspek yang kompleks. ${ }^{2}$

Di antara efektifitas dari pembelajaran imla' yaitu mengetahui kaidah penulisan huruf dan kata-kata dengan baik dan benar, memperbagus tulisan arab, melatih kemampuan istima' (mendengar), melatih konsentrasi berfikir dan membiasakan diri untuk bersabar dalam menulis. ${ }^{3}$

Sesuai dengan karakteristik bahasa Arab, baik dalam aspek fonologis, morfologis, sintaksis dan semantiknya, Imla' sebagai salah satu cabang bahasa Arab bagi sebagian mahasiswa dianggap sebagai kemampuan yang tidak mudah. Sebab banyak ditemukan perbedaan antara bahasa yang terucap dengan yang tertulis. Perbedaan ini menyebabkan kesulitan bagi sebagian mahasiswa. Ada sebagian huruf yang tidak diucapkan tetapi harus ditulis sehingga menyebabkan banyak kesulitan sekaligus kesalahan berbahasa atau sebaliknya.

Kesalahan bahasa secara garis besar dapat diklasifikasikan menjadi dua macam yaitu kesalahan perfomance dan kesalahan kompetensi. Kesalahan perfomance merupakan kesalahan berbahasa yang disebabkan oleh faktor keletihan, kelelahan dan kurangnya perhatian dari pembelajar bahasa. Jadi, kesalahan bahasa dalam konteks ini lebih disebabkan oleh faktor diri pembelajar bahasa yang bersangkutan. Sementara kesalahan kompetensi adalah kesalahan bahasa yang disebabkan oleh ketidaktahuan pembelajar mengenai kaidah-kaidah bahasa. ${ }^{4}$ Jadi lebih terkait dengan aspek pengetahuan pembelajar tentang kaidah bahasa.

Menurut As Shini dan Al Amin, bahwa kesalahan bahasa dapat terjadi dalam dua aspek yaitu aspek intralingual dan aspek developmental. Kesalahan intralingual dimaksudkan sebagai kesalahan-kesalahan bahasa yang terjadi ketika pembelajar mengenal kaidah bahasa, melakukan kesalahan generalisasi dalam kaidah tertentu, tidak dapat mengaplikasikan kaidah bahasa secara sempurna, atau kurang sesuai dengan konteksnya. Sedangkan kesalahan developmental adalah kesalahan yang dilakukan oleh pembelajar berkenaan dengan bahasa atas dasar asumsi yang dibangunnya selama pembelajaran di kelas dalam situasi terbatas. ${ }^{5}$

Senada dengan As Sini dan Al Amin di atas, Tarigan juga menjelaskan wilayah atau daerah kesalahan bahasa sering terjadi dalam empat aspek yaitu generalisasi, ketidaktahuan kaidah bahasa, penerapan-penerapan kaidah bahasa yang kurang sempurna serta asumsi tentang bahasa

2 Achmad Yusuf, "Strategi Genius Learning Dalam Pembelajaran Maharatul Kitabah,” Studi Arab 9, no. 2 (2018): 161-176.

3 Wakhidatur Rizqiyah, “تنفيذ الطريقة لوالقائية وي درس الإملاء," al Mahāra: Jurnal Pendidikan Bahasa Arab 4, no. 1 (2018): 149-158.

${ }^{4}$ H Tarigan, "Pengajaran Analisis Kesalahan Berbahasa.(2011, Ed.)” (Bandung, 2011).

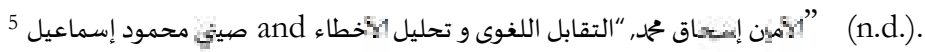


yang salah. ${ }^{6}$ Kesalahan-kesalahan ini sangat mungkin terjadi pada diri pembelajar ketika mempelajari bahasa asing atau bahasa kedua.

Pengajar harus tahu jenis kesalahan yang dilakukan oleh pembelajar terlebih dahulu sebelum melakukan analisis lanjutan. Terdapat dua jenis kesalahan berbahasa yakni, 1) kesalahan terbuka dan 2) kesalahan tertutup. Kesalahan terbuka adalah kesalahan berbahasa pada tingkat ketatabahasaan yang terlihat dalam kalimat-kalimat yang dihasilkan pembelajar. Kesalahan tertutup merupakan kesalahan yang tersembunyi di balik kalimat yang tersusun secara benar menurut tata bahasa, tetapi tidak benar dari sudut semantiknya. Lebih lanjut kesalahan-kesalahan berbahasa terjadi karena adanya kesulitan dari diri pembelajar mempunyai arti yang penting dalam penelitian, artinya dapat diketahui bukti tentang cara bahasa itu dipelajari dan dapat diketahui strategi atau metode yang tepat untuk pembelajarannya. ${ }^{7}$

Imla' merupakan salah satu unsur bahasa Arab dengan kaidah-kaidah penulisan yang cukup rumit, meskipun pembelajar memiliki konsentrasi dalam pembelajaran bahasa Arab. Khususnya bagai pembelajar yang tidak menggunakan bahasa Arab sebagai bahasa komunikasi keseharian.

Hal ini dapat disebabkan oleh karena bahasa Arab merupakan bahasa asing berbeda dengan bahasa pertama, baik dalam segi fonologi, morfologi, sintaksis maupun semantik. Perbedaan ini menimbulkan problem tersendiri bagi pembelajar bahasa Arab termasuk dalam penulisannya. Juga imla' mempunyai kaidah tersendiri, oleh karena itu untuk memahami dan menguasainya, pembelajar membutuhkan waktu yang memadai.

Problem ini juga dapat dilihat dan diketahui dalam penulisan skripsi berbahasa Arab bagi mahasiswa Program Studi Pendidikan Bahasa Arab, meskipun mereka telah menyelesaikan beberapa mata kuliah bahasa Arab. Oleh sebab itu, penelitian ini memfokuskan pada kesalahan imla' bagi mahasiswa Program Studi Pendidikan Bahasa Arab IAIN Salatiga.

\section{Metode}

Penelitian ini merupakan penelitian lapangan yang dilaksanakan bagi mahasiswa Program Studi Pendidikan Bahasa Arab IAIN Salatiga. Kesalahan-kesalahan Imla' dikumpulkan melalui tes tertulis yang dilakukan selama pembelajaran qawaid imla' untuk pembelajar yang berjumlah 59 mahasiswa.

Metode analisis bahasa adalah analisis bahasa dengan standar bahasa yang bersangkutan yang dipakai oleh pengguna. Senada dengan pemahaman tersebut, Sudaryanto

\footnotetext{
${ }^{6}$ Tarigan, "Pengajaran Analisis Kesalahan Berbahasa.(2011, Ed.)."

${ }^{7}$ Soenardji, Panduan Pengajaran Sendi-Sendi Linguistika Bagi Kepentingan Pengajaran Bahasa (Jakarta: Departemen Pendidikan dan Kebudayaan, 1989).
} 
mengidentifikasinya dengan nama metode agih. Metode agih adalah metode analisis bahasa yang alat penentunya berasal dari bahasa yang bersangkutan. ${ }^{8}$

Michael McCarthy menjelaskan langkah-langkah analisis bahasa menjadi enam langkah. Pertama, mengumpulkan data-data kesalahan bahasa yang dilakukan pembelajar (collecting data), kedua, mengidentifikasi kesalahan-kesalahan bahasa yang dilakukan oleh pembelajar (identifying errors), ketiga, mengklasifikasi kesalahan-kesalahan bahasa berdasar unit atau daerah kesalahan masing-masing (classifying errors), keempat, mengukur kesalahan-kesalahan bahasa yang terjadi (quantifying errors), kelima, menganalisis sumber terjadinya kesalahan (analyzing source of error), dan keenam, memperbaiki kesalahan yang dilakukan oleh pembelajar (remediating for errors). ${ }^{9}$

Senada dengan pendapat di atas, Tarigan mengemukakan enam langkah dalam hal ini, yaitu 1) mengumpulkan data kesalahan, 2) mengidentifikasi dan mengklasifikasi kesalahan, 3) memeringkatkan kesalahan, 4) menjelaskan kesalahan, 5) memprediksi daerah atau butir kebahasaan yang rawan kesalahan, dan 6) memperbaiki kesalahan. ${ }^{10}$ Dalam menganlisis kesalahan imla' sebagai bagian kesalahan bahasa, penggunaan enam langkah tersebut dapat dilakukan, sehingga ditemukan wilayah kesalahan imla', frekeunsi masing-masing kesalahan dan upaya perbaikannya.

Corder, seorang tokoh bahasa, menjelaskan tiga langkah dalam menganalisis kesalahan berbahasa secara umum, yaitu pertama, mengumpulkan data-data kesalahan bahasa yang dilakukan oleh pembelajar, (data collection), kedua, mengidentifikasi kesalahan-kesalahan bahasa yang dilakukan oleh pembelajar serta menjelaskan daerah atau wilayah kesalahannya (identification and description), ketiga, menjelaskan kesalahan-kesalahan bahasa serta menjelaskan pula standar bahasa yang benar (explanation). ${ }^{11}$

Dalam penelitian ini, langkah-langkah analisis kesalahan imla' sebagai bagian analisis kesalahan bahasa mengikuti tiga langkah tersebut di atas, yaitu pertama, mengumpulkan data kesalahan bahasa yang dilakukan oleh mahasiswa, kedua, mengidentifikasi dan mengklasifikasi kesalahan-kesalahan bahasa dan menjelaskan daerah atau wilayah kesalahannya, ketiga, menjelaskan kesalahan-kesalahan bahasa dan menjelaskan pula standar bahasa yang benar.

Dengan mengikuti langkah-langkah tersebut, diharapkan mahasiswa memiliki wawasan yang memadai tentang ragam kesalahan dalam bahasa Arab khususnya imla', sekaligus memahami daerah atau wilayah kesalahan masing-masing dengan berpedoman pada kaidah imla'.

\footnotetext{
${ }^{8}$ Sudaryanto, Metode Dan Aneka Teknik Analisis Bahasa: Pengantar Penelitian Wahana Kebudayaan Secara Linguistis (Duta Wacana University Press, 1993).

${ }_{9}^{9}$ Michael McCarthy, Discourse Analysis for Language Teachers (Cambridge University Press, 1991).

${ }^{10}$ Tarigan, "Pengajaran Analisis Kesalahan Berbahasa.(2011, Ed.)."

${ }^{11}$ Stephen Pit Corder, "Error Analysis," The Edinburgh course in applied linguistics 3 (1974): 122-131.
} 


\section{Hasil dan Pembahasan}

\section{Kesalahan Berbahasa}

Kesalahan berbahasa secara sederhana dapat dimaknai sebagai penyimpangan atau kesalahan dari kaidah baku bahasa tersebut, baik dalam bahasa tertulis atau bahasa lisan. Dengan ungkapan lain, kesalahan berbahasa didefinisikan sebagai penyimpangan dari standar berbahasa yang baik dan benar sesuai dengan penutur aslinya. Jadi standar pengukurnya adalah penutur aslinya, baik dalam bahasa tulis maupun lisan. Jika kesalahan dalam bahasa Indonesia, berarti alat pengukurnya adalah penutur asli bahasa Indonesia atau kaidah yang sudah dibakukan, jika kesalahan dalam bahasa Arab, maka alat pengukurnya adalah penutur asli bahasa Arab baik dalam bahasa tulis maupun lisan. Dalam bahasa tulis untuk bahasa Arab menggunakan kaidah-kaidah imla' sebagai standar baku kaidah bahasa Arab.

Berkenaan dengan kesalahan tersebut, Pateda menjelaskan bahwa kesalahan berbahasa adalah penyimpangan-penyimpangan yang bersifat sistematis yang dilakukan oleh terdidik (siswa/mahasiswa) ketika ia menggunakan bahasa. ${ }^{12}$ Dalam konteks ini bahasa dapat berupa aspek lisan maupun tertulis, sebagai wujud keterampilan berbahasa.

Kesalahan-kesalahan dalam bahasa Arab sangat bervariasi. Zahran mengklasifikasikan kesalahan berbahasa Arab menjadi empat macam. Pertama, kesalahan dalam penulisan dan bunyi bahasa (al akhtá al imlãiyah wa soutiyah), kedua, kesalahan dalam morfologi (al akbtá al sarfiyah), ketiga, kesalahan dalam sintaksis (al akhtá al nahwiyah), keempat, kesalahan semantik (al 'akbtá al dilãliyab). ${ }^{13}$

Kesalahan penulisan dan bunyi bahasa (fonologi) sering terjadi dalam penulisan. Kesalahan ini menyangkut beberapa hal antara lain, kesalahan penulisan huruf, kesalahan titik, kesalahan tata urut huruf dalam kata, kesalahan menulis kata. Secara etimologi, kata fonologi terambil dari fon yaitu bunyi, dan logi yaitu ilmu. Maksudnya, fonologi adalah salah satu bidang kajian linguistik yang mempelajari, menganalisis, dan membicarakan runtutan bunyi-bunyi bahasa. ${ }^{14}$

Kesalahan morfologi sering terjadi dalam penulisan bentuk kata. Morfologi dimaknai dengan ilmu yang mempelajari tentang bentuk kata dan bagian-bagiannya. Dalam bahasa Arab, morfologi ini dapat disejajarkan dengan ilmu tashrif yang membahas tentang perubahan bentuk kata. Satu kata dapat berubah menjadi beberapa kata yang baru dengan makna yang baru pula.

Kesalahan sintaksis merupakan kesalahan yang berkenaan dengan kesalahan frase dan kalimat. Sebab, sintaksis merupakan cabang ilmu yang memfokuskan pada aspek wacana, kalimat,

\footnotetext{
12 Pateda Mansoer, “Analisis Kesalahan,” Nusa Indah. Flores, NTT (1989).

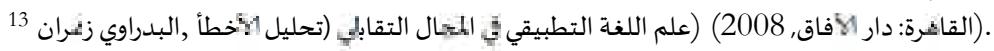

${ }^{14}$ Chaer Abdul, “Linguistik Umum,” Jakarta: Rineka Cipta (2007).
} 
klausa dan frase. Oleh sebab itu kesalahan sintaksis adalah kesalahan yang menyangkut wacana, kalimat, dan frase.

Kesalahan wacana, kalimat atau frase dalam bahasa Arab sepadan dengan kajian ilmu nahwu. Sebab ilmu nahwu mengkaji tentang susunan kalimat dan kajian tentang jabatan kata dalam kalimat. Kesalahan semantik merupakan kesalahan yang menyangkut makna suatu kata, sehingga menyangkut makna kata dan strukturnya.

Sebagian ahli bahasa mengklasifikasikan kesalahan bahasa Arab menjadi lima macam. Pertama, kesalahan struktural (al akhtha' al tarkibiyah), kedua, kesalahan morfologi (al akbta' al sarfiyah), ketiga, kesalahan fonologi (al akbta' al soutiyah), keempat, kesalahan semantik (al 'akbta' al dilãliyah) dan kelima, kesalahan penulisan kata (al akhtha' al imlãiyah).

Analisis kesalahan bahasa pada hakikatnya merupakan kajian tentang kesalahan bahasa yang dilakukan oleh pembelajar yang bertujuan membantu pembelajar agar lebih berhasil dalam belajar bahasa kedua. Dengan demikian, kajian analisis kesalahan imla' bertujuan untuk membantu pembelajar dalam hal ini mahasiswa untuk dapat mempelajari imla' secara mudah dalam waktu yang singkat, serta dapat menulis teks bahasa Arab dengan benar.

Jika analisis kesalahan bahasa merupakan kajian tentang kesalahan bahasa yang dilakukan oleh pembelajar dengan tujuan membantu pembelajar agar lebih berhasil dalam belajar bahasa kedua dan dapat memperbaiki sekaligus menghindari pemakaian bahasa yang salah, maka analisisnya harus didasarkan pada standar baku bahasa tersebut sebagai pedoman.

\section{Kesalahan Imla'}

Kesalahan tulis dapat terjadi dalam penulisan, khususnya dalam bahasa Arab. Kesalahan itu disebabkan penulisan dari bahasa lisan yang sering terjadi antara yang terucap dan tertulis dapat berbeda. Kesalahan ini menyangkut beberapa hal antara lain, kesalahan penulisan huruf terutama huruf-huruf yang mirip, kesalahan titik pada huruf yang mirip dari aspek bunyi, kesalahan tata urut huruf dalam kata, dan kesalahan menulis kata (mufradat).

Kesalahan penulisan kata merupakan kesalahan yang senantiasa melibatkan kesalahan dalam menulis huruf-huruf tertentu seperti hamzah dan huruf-huruf illat, juga tata cara penyambungan dan pemisahannya. Dalam imla' kesalahan-kesalahan tulis sering terjadi, khususnya dalam menulis huruf-huruf tertentu yang mempunyai kaidah yang berbeda-beda. Misalnya menulis huruf hamzah di awal kata dapat dibedakan menjadi dua macam yaitu hamzah washal dan hamzah qatha'. Dua hamzah di awal kata ini dalam tata tulis jelas berbeda. Hamzah washal ditulis tanpa menggunakan tanda hamzah di atas atau di bawah huruf alif, sementara hamzah qatha' ditulis disertai tanda hamzah di atas atau di bawah huruf alif. Dari aspek bunyi hamzah washal tanpa dibaca ketika didahului dengan kata lain, sementara hamzah qatha' tetap harus dibaca baik ketika didahului kata lain atau tidak. Hamzah washal yang tidak dibaca ketika 
didahului dengan kata lain akan membuat kesalahan pembelajar bahasa Arab manakala dia tidak memahami dan menguasai kaidah hamzah washal secara utuh.

Demikian juga menulis huruf hamzah di tengah kata mempunyai beberapa kaidah yang banyak. Kadang hamzah di tengah kata ditulis di atas huruf alif, dalam kesempatan lain ditulis di atas huruf wawu, serta di kesempatan lain lagi ditulis di atas huruf ya' tanpa titik. Dengan demikian, penulisan hamzah dapat menyebabkan kesalahan pembelajar bahasa Arab dalam menulis kata yang mengandung huruf hamzah, apabila yang bersangkutan kurang memahami kaidah-kaidah penulisan hamzah.

Kesalahan ini terjadi, akibat penulisnya tidak mengetahui kaidah imla'iyyah yang benar. Meskipun jumlah kesalahan ini lebih bersifat teknis, dalam berbagai kasus karangan dan terjemahan (ke dalam bahasa Arab), kesalahan tulis ini masih cukup dominan contohnya aliimun, umm, dengan menggunakan alif tanpa tanda hamzah. ${ }^{15}$

Oleh karena diantara faktor kesalahan mahasiwa dalam imla' secara umum disebabkan belum menguasai kaidah-kaidah penulisan hamzah baik diawal, tengah maupun akhir kata. ${ }^{16}$ Dengan demikian, kajian kesalahan berbahasa Arab dalam bidang Imla' juga mempunyai peran yang penting dalam pembelajaran bahasa Arab.

\section{Kesalahan Imla' Mahasiswa}

Setelah data terkumpul dan mempertimbangkan kaidah-kaidah imla', selanjutnya peneliti mengidentifikasi kesalahan-kesalahan imla' yang dilakukan oleh mahasiswa dan mengklasifikasikannya sesuai dengan daerah atau wilayah kesalahan masing-masing. Berdasarkan identifikasi tentang daerah atau wilayah kesalahan imla' dapat diklasifikasikan menjadi sembilan kesalahan sebagai berikut:

1. Kesalahan dalam menulis kosa kata yang sebagian hurufnya mirip dari aspek bunyi.

\begin{tabular}{|c|c|c|}
\hline No. & Kesalahan penulisan huruf pada kata yang mirip & Penulisan yang benar \\
\hline 1 & ويتبادل معهم الرعي & ويتبادل معهم الرأي \\
\hline 2 & سعيا وراء عمور ديثهم & سعيا وراء أمور ديثهم \\
\hline 3 & دخلت الشيعة الشمس الغرفة & دخلت أشعة الشمس الغرفة \\
\hline 4 & أولئك هم سر البرية & أولئك هم شر البرية \\
\hline 5 & عليك ألا تعجل فرصتك & عليك ألا تؤجل فرصتك \\
\hline
\end{tabular}

${ }^{15}$ Muhbib Abdul Wahab, Epistemologi Dan Metodologi Pembelajaran Bahasa Arab (UIN Jakarta Press, 2008).

16 Ahmad Muradi, “Wâqi'Ta'lîm Mahârah Al-Kitâbah Bi Indûnîsiyyâ Musykilatan Wa Hulûlan,” Arabiyat: Jurnal Pendidikan Bahasa Arab Dan Kebahasaaraban 5, no. 1 (2018): 155-170. 
20 | Volume 11, Nomor 1, Juni 2020

\begin{tabular}{|c|c|c|}
\hline 6 & فتقعد ملوها محسيورو ا & فتقعد ملوها هحسيورو ا \\
\hline 7 & يِعطي الحكمة من يشـاء & يؤتي الحكمة من يشـاء \\
\hline 8 & مخلسين لله الدين & مخلصين لـه الدين \\
\hline
\end{tabular}

2. Kesalahan dalam mengidentifikasi hamzah washal dalam kata yang dibaca secara washal.

\begin{tabular}{|c|c|c|}
\hline No. & Kekurangan penulisan hamzah washal & Penulisan yang benar \\
\hline 1 & فرتدى أحمد ملإِسـا & فارتدى أحمد ملإِسـا \\
\hline 2 & وتبع ملة إبراهيم حنيفا & واتبع ملة إبراهيم حنيفا \\
\hline 3 & 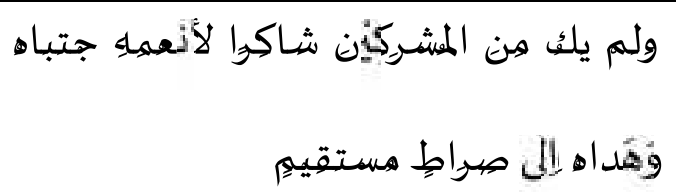 & 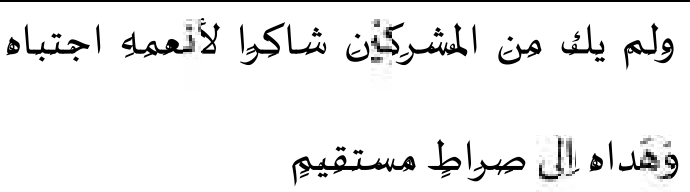 \\
\hline 4 & أن تبع هلةً إبراهيم حنيفا & أن اتبع هلةً إبراهيميم حنيفا \\
\hline
\end{tabular}

3. Kesalahan menambah al syamsiyah pada kalimat-kalimat tertentu.

\begin{tabular}{|c|c|c|}
\hline No. & $\begin{array}{c}\text { Kesalahan menambah al syamsiyah pada kata } \\
\text { tertentu }\end{array}$ & Penulisan yang benar \\
\hline 1 & أوحى الله إلى النبيهم & أوحى الله إلى نبيهم \\
\hline 2 & في النار جهنم خالدين فيها & في نار جهنم خالدين فيها \\
\hline 3 & لا فرق بين ذكر والانثى & لا فرق باين ذكر والانثى \\
\hline 4 & لرسالة الإسلام كالتقوى والجهياد وعلم & لرسالة الخساملام كالتقوى والجهاد والعلم \\
\hline
\end{tabular}

4. Kesalahan dalam menulis tanda hamzah qatha' dalam kalimat tertentu.

\begin{tabular}{|c|c|c|}
\hline No. & Kesalahan menulis tanda hamzah qatha' & Penulisan yang benar \\
\hline 1 & كان المسلمون يسمعون ما اوحى الله الى & كان المسلمون ديسمعون ما أوحى الله إلى نبيهم \\
\hline 2 & اصبح المركز السياسي للجماعة كلها & أصبح المركز السياسي للجماعـة كلها \\
\hline
\end{tabular}




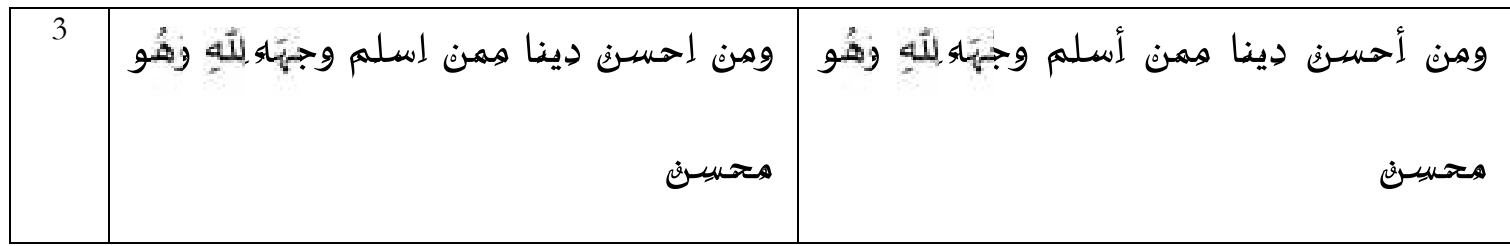

5. Kesalahan dalam menulis ta' marbuthah dengan huruf ha' pada kalimat tertentu yang diwaqaf.

\begin{tabular}{|c|c|c|}
\hline No. & $\begin{array}{l}\text { Kesalahan menulis ta' marbuthah dengan huruf } \\
\text { ha' }\end{array}$ & Penulisan yang benar \\
\hline 1 & أولئك هم شر البريه & أولئك هم شـر اليرية \\
\hline 2 & وذلك دين القيمه & وذلك دين القيمة \\
\hline 3 & أمر نابِع من مبـأ المسـاواه & أمر نايِح من مبـدأ المسـاواة \\
\hline
\end{tabular}

6. Kesalahan dalam menulis kata yang diakhiri dengan alif layyinah dengan model huruf alif atau dengan mirip huruf ya tanpa titik.

\begin{tabular}{|c|c|c|}
\hline No. & Kesalahan menulis alif layyinah di akhir kata & Penulisan yang benar \\
\hline 1 & كعى الله تَعالى & ودعا اللَه تحعالى \\
\hline 2 & وأن ليّس للإنسـان إلإ ما سعا & وأن ليس للإذسـان إلا ما سعى \\
\hline
\end{tabular}

7. Kesalahan dalam menulis ta' maftuhah dengan ta' marbuthah dalam teks bahasa Arab.

\begin{tabular}{|c|c|c|}
\hline No. & $\begin{array}{c}\text { Kesalahan menulis ta' maftuhah dengan ta' } \\
\text { marbuthah }\end{array}$ & Penulisan yang benar \\
\hline 1 & فيتخذ ما يرى من القراراة & فيتخذ ما يرى من القرارات \\
\hline 2 & من أية القرآن الكريم & من آيات القرآن الكر.يم \\
\hline
\end{tabular}

8. Kekurangan menulis alif tafriq setelah wawu jama' pada fi'il.

\begin{tabular}{|c|c|c|}
\hline No. & Kekurangan menulis alif tafriq & Penulisan yang benar \\
\hline 1 & وما أمروا إلا ليعبد الله مخلصين له الدين & وما أمروا إلا ليعبدوا الله مخلصين له الدين \\
\hline 2 & ويقيم الصلاة ويؤتو الزكاة & ويقيموا الصلاة ويؤتوا الزكاة \\
\hline
\end{tabular}


9. Kesalahan dalam menulis hamzah di tengah kata yang kadang ditulis di atas huruf alif, wawu atau ya tanpa titik.

\begin{tabular}{|c|c|c|}
\hline No. & Kesalahan menulis hamzah di tengah kata & Penulisan yang benar \\
\hline 1 & 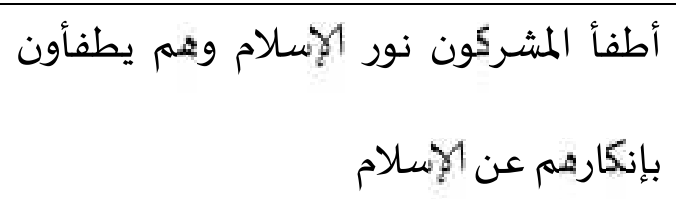 & 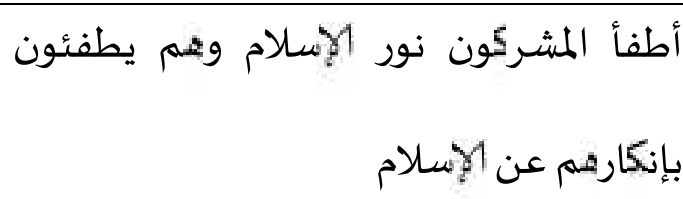 \\
\hline 2 & سأل الله عن أعمالنا وسـأل المسلمون عن & سأعماله الله عن أعمالنا وسئل المسلمون عن \\
\hline
\end{tabular}

Kesalahan-kesalahan yang terjadi lebih banyak pada proses mentransfer suara ke dalam rumus bahasa dan hanya mengandalkan pada bunyi semata-mata. Padahal dalam imla' terdapat beberapa huruf yang tidak dibaca secara jelas ketika dibaca bersamaan dengan kata sebelumnya. Berikut ini adalah persentase kesalahan imla' mahasiswa :

\begin{tabular}{|c|l|c|}
\hline No. & \multicolumn{1}{|c|}{ Daerah Kesalahan Imla' } & Persentase \\
\hline 1 & Kesalahan menulis huruf yang mirip & 26,5 \\
\hline 2 & Kesalahan menulis hamzah washal & 13,5 \\
\hline 3 & Kesalahan menulis al syamsiyah & 13,5 \\
\hline 4 & Kesalahan menulis ta' marbuthah & 10,25 \\
\hline 5 & Kesalahan menulis tanda hamzah qatha' & 10,25 \\
\hline 6 & Kesalahan menulis hamzah di tengah kata & 6,5 \\
\hline 7 & Kekurangan menulis alif tafriq & 6,5 \\
\hline 8 & Kesalahan menulis alif layyinah di tengah kata & 6,5 \\
\hline 9 & Kesalahan menulis ta' maftuhah & 6,5 \\
\hline
\end{tabular}

Berdasarkan data di atas dapat diketahui beberapa hal. Pertama, wilayah kesalahan terjadi dalam sembilan poin. Kedua, persentase atau frekwensi kesalahan imla' dalam masing-masing poin sebagaimana dapat dilihat dalam tabel di atas.

Kesalahan pertama, kesalahan yang terjadi pada penulisan huruf yang mirip dalam suatu kata sebesar 26,5 \% sebagaimana data di atas. Kesalahan ini paling banyak terjadi dalam mengidentifikasi kosakata yang mempunyai huruf yang mirip, bahkan kemiripan dalam makna seperti yu'thi dengan $y u^{\prime} t i$.

Kesalahan kedua, kesalahan yang terjadi pada kekurangan penulisan hamzah washal pada kata-kata yang seharusnya diawali dengan hamzah washal sebesar 13,5\%. Kesalahan ini terjadi pada hamzah washal yang dibaca secara washal dengan kata sebelumnya. 
Kesalahan ketiga, kesalahan menuliskan al syamsiyah pada kata yang semestinya tidak dituliskan dengan al syamsiyah sebesar 13,5\%. Kesalahan ini dapat diminimalisir dengan pemahaman kaidah nahwu secara baik, terutama pada pemahaman konteks idhäfah.

Kesalahan keempat, kesalahan yang terjadi pada penulisan ta' marbuthah, meskipun berbunyi huruf $h a^{\prime}$ sebesar 10,25\%. Kesalahan ini dapat diminimalisir dengan pemahaman tempat ta' marbuthah dan ta' maftuhah. Masing-masing dari kedua ta' ini mempunyai kaidah sendiri-sendiri.

Kesalahan kelima, kesalahan menuliskan tanda hamzah pada kata-kata yang diawali dengan tanda hamzah qatha' sebesar 10,25\%. Ada kalimat tertentu yang awalnya merupakan hamzah qatha'. Dari data di atas, ditemukan beberapa kesalahan dalam menulis hamzah qatha' yang dilakukan oleh mahasiswa.

Kesalahan keenam, kesalahan dalam menulis hamzah di tengah kata sebesar 6,5\%. Mahasiswa melakukan kesalahan dalam menulis kata yutfi'una dan kata su'ila seharusnya ditulis dengan hamzah di atas wawn pada yutfi'ûna dan dengan hamzah ditulis di atas ya' pada kata su'ila.

Kesalahan ketujuh, kesalahan atau kekurangan alif tafriq setelah wawu jama' pada fi'il sebesar 6,5\%. Mahasiswa melakukan kesalahan dalam menulis kata ya'budu, yuqimu, yu'tu, seharusnya disertai dengan wawu jama' dan alif tafriq.

Kesalahan kedelapan, kesalahan menulis alif layyinah di tengah kata sebesar 6,5\%. Dalam konteks ini mahasiswa melakukan kesalahan dalam menulis kata da'ã dengan alif dengan bentuk alif panjang, dan kata sa'ã dengan alif bentuk $y a$ '.

Kesalahan kesembilan, kesalahan menulis ta' marbuthah pada kata-kata tertentu yang semestinya ditulis dengan ta' maftuhah sebesar 6,5\%. Dalam konteks ini mahasiswa melakukan kesalahan dalam menulis kata al qararãh dan kata ayãt yang semestinya ditulis dengan ta' maftuhah.

\section{Upaya Perbaikan Kesalahan Imla'}

Kesalahan-kesalahan dalam imla' mahasiswa lebih banyak pada aspek fonologi atau bunyi yakni mentransfer suara ke dalam rumus bahasa, mahasiswa hanya mengandalkan pada bunyi semata-mata ketika menulis. Padahal dalam imla' ada beberapa huruf yang tidak dibaca secara jelas ketika dibaca bersamaan dengan kata sebelumnya.

Dari sembilan wilayah kesalahan dalam menulis imla' di atas, sebenarnya kesalahan nomor satu sampai dengan kesalahan nomor empat merupakan kesalahan menulis yang disebabkan pada bunyi rumus bahasa. Kesalahan nomor satu yaitu kesalahan huruf pada kata tertentu disebabkan kemiripan pada bunyi huruf hija'iyah yang dibaca. Kesalahan kedua yaitu kesalahan atau kekurangan pada penulisan hamzah washal disebabkan pula karena bunyi hamzah dalam kata-kata tertentu tersebut tidak terbaca sehingga menimbulkan anggapan tidak ada huruf. Kesalahan ketiga yaitu kesalahan menambahkan al syamsiyah disebabkan pula oleh persoalan bunyi bahasa. 
Kesalahan keempat yaitu kesalahan merubah huruf ta' marbuthah dengan suara huruf $h a^{\prime}$ ketika diwaqaf juga termasuk persoalan bunyi bahasa.

Untuk memperbaiki kesalahan pada aspek fonologi khususnya wilayah yang pertama ini mahasiswa harus mempunyai pemahaman yang komprehensif terkait dengan kosakata. Mahasiswa seharusnya memahami arti kosakata tersebut, memahami asal usul kosakata tersebut apabila berasal dari kata kerja, juga memahami konteksnya. Mahasiswa perluya meningkatkan intensitas membaca teks-teks berbahasa Arab sehingga pemahaman kosakata akan bertambah dengan sendirinya.

Untuk kesalahan yang kedua, berkenaan dengan hamzah washal, mahasiswa harus mempunyai pemahaman komprehensif tentang kaidah hamæah washal dan tempat-tempatnya. Sebagaimana dalam pembelajaran kaidah, maka sebenarnya dapat dilakukan dengan langkahlangkah; pertama, pengenalan kaidah, kedua, praktik kaidah. Dalam pengenalan kaidah hamzah washal dan tempat-tempatnya, mahasiswa harus dapat menghafal kaidah hamzah washal secara utuh. Dalam mengenalkan kaidah ini dapat dipergunakan metode deduktif atau induktif.

Pengenalan kaidah imla' dengan menggunakan metode induktif mengikuti langkah-langkah berikut:

1. Menyajikan contoh-contoh kaidah imla' sebanyak-banyaknya;

2. Menjelaskan contoh terkait dengan kaidah imla';

3. Menarik kesimpulan berupa kaidah-kaidah imla'.

Adapun pengenalan kaidah imla' dengan menggunakan metode deduktif mengikuti langkah-langkah berikut:

1. Menyajikan kaidah-kaidah imla' secara ringkas;

2. Menjelaskan kaidah-kaidah imla';

3. Membuat contoh sebanyak-banyaknya.

Sedangkan langkah yang kedua merupakan langkah yang paling penting dan tujuan akhir dari pengenalan kaidah yaitu menerapkan kaidah hamzah washal. Untuk menerapkan kaidah-kaidah imla' pengajar harus memberi ruang sebanyak-banyaknya sehingga memungkinkan pembelajar mempraktikkan seluruh kaidah tersebut dengan baik dan akhirnya dapat menguasainya.

\section{Kesimpulan}

Berdasarkan pembahasan dan analisis di atas, maka dapat diambil kesimpulan sebagai berikut; Pertama, daerah kesalahan imla' yang dilakukan oleh mahasiswa Program Studi Pendidikan Bahasa Arab terdapat sembilan daerah. Sembilan daerah kesalahan tersebut yaitu 1). kesalahan yang terjadi pada penulisan huruf yang mirip dalam suatu kata, 2). kekurangan penulisan hamzah washal pada kata-kata yang seharusnya diawali dengan hamzah, 3). kesalahan 
penulisan al syamsiyah pada kata yang seharusnya tidak ditulis dengan al syamsiyah, 4). kesalahan yang terjadi pada penulisan ta' marbuthah, 5). kesalahan penulisan tanda hamzah pada kata-kata yang diawali dengan tanda hamzah qatha', 6). kesalahan dalam menulis hamzah di tengah kata, 7). kesalahan atau kekurangan alif tafriq, 8). kesalahan penulisan alif layyinah di tengah kata, 9). kesalahan penulisan ta' marbuthah pada kata-kata tertentu yang semestinya ditulis dengan $t a$ ' maftubah.

Kedua, frekeunsi kesalahan imla’ yang dilakukan oleh mahasiswa Program Studi Pendidikan Bahasa Arab sebagai berikut. pertama, kesalahan yang terjadi pada penulisan huruf yang mirip dalam suatu kata sebesar 26,5 \%. Kesalahan kedua, kekurangan menuliskan hamæah washal pada kata-kata yang seharusnya diawali dengan hamzah washal sebesar 13,5\%. Kesalahan ketiga, kesalahan menuliskan al syamsiyah pada kata yang seharusnya tidak dituliskan dengan al syamsiyah sebesar 13,5\%. Kesalahan keempat, kesalahan yang terjadi pada penulisan ta' marbuthah sebesar 10,25\%. Kesalahan kelima, kesalahan menuliskan tanda hamzah pada kata-kata yang diawali dengan tanda hamzah qatha' sebesar 10,25\%. Kesalahan keenam, kesalahan dalam menulis hamzah di tengah kata sebesar 6,5\%. Kesalahan ketujuh, kesalahan atau kekurangan alif tafriq sebesar 6,5\%. Kesalahan kedelapan, kesalahan menulis alif layyinah di tengah kata sebesar 6,5\%. Kesalahan kesembilan, kesalahan menulis ta' marbuthah pada kata-kata tertentu yang semestinya ditulis dengan ta' maftuhah sebesar 6,5\%.

Ketiga, upaya yang dilakukan untuk meminimalisir kesalahan-kesalahan imla' di atas adalah sebagai berikut. Kesalahan yang berkenaan dengan kosakata, sebaiknya pengajar memberi kesempatan mahasiswa untuk banyak membaca literatur berbahasa Arab sehingga penguasaan kosa kata menjadi cukup. Di samping itu, pengajar dapat membuat daftar contoh kata yang mirip dari sisi bunyi atau maknanya sehingga memudahkan mahasiswa untuk mengidentifikasinya.

\section{Daftar Pustaka}

Abdul, Chaer. "Linguistik Umum.” Jakarta: Rineka Cipta (2007).

Al-Ghalayini, Mustafa. Jamial-Durus Al-Arabiyah. Darul Fikir, 2009.

Corder, Stephen Pit. "Error Analysis." The Edinburgh course in applied linguistics 3 (1974): 122-131.

Mansoer, Pateda. “Analisis Kesalahan.” Nusa Indah. Flores, NTT (1989).

McCarthy, Michael. Discourse Analysis for Language Teachers. Cambridge University Press, 1991.

Muradi, Ahmad. "Wâqi’Ta'lîm Mahârah Al-Kitâbah Bi Indûnîsiyyâ Musykilatan Wa Hulûlan." Arabiyat: Jurnal Pendidikan Bahasa Arab Dan Kebahasaaraban 5, no. 1 (2018): 155-170.

Rizqiyah, Wakhidatur. “تولنفيذ الطريقة الإلقائية في درس الإملاء." al Mahāra: Jurnal Pendidikan Bahasa Arab 4, no. 1 (2018): 149-158. 
26 | Volume 11, Nomor 1, Juni 2020

Soenardji. Panduan Pengajaran Sendi-Sendi Linguistika Bagi Kepentingan Pengajaran Bahasa. Jakarta:

Departemen Pendidikan dan Kebudayaan, 1989.

Sudaryanto. Metode Dan Aneka Teknik. Analisis Bahasa: Pengantar Penelitian Wahana Kebudayaan Secara Linguistis. Duta Wacana University Press, 1993.

Tarigan, H. "Pengajaran Analisis Kesalahan Berbahasa.(2011, Ed.).” Bandung, 2011.

Wahab, Muhbib Abdul. Epistemologi Dan Metodologi Pembelajaran Bahasa Arab. UIN Jakarta Press, 2008.

Yusuf, Achmad. "Strategi Genius Learning Dalam Pembelajaran Maharatul Kitabah.” Studi Arab 9, no. 2 (2018): 161-176.

إسأمين إسعاق محمد. “التقابل اللغوى و تحليل الاخطاء and"d.). (n.d.).

زهران, البدراوي. علم اللغة التطبيقي في المجال التقابلي (تحليل الاخطأ). القاهرة: دار الآفاق, 2008. 